\title{
PROBLEMATICS AND LEGAL DIMENSIONS IN ARRANGEMENT OF SPACE ACCORDING TO LAW NUMBER 26 OF 2007
}

\author{
Amiludin and Muhammad Asmawi \\ Universitas Muhammadiyah Tangerang, \\ Universitas Banten Jaya Serang Banten
}

Jalan Perintis Kemerdekaan I Babakan No.33, RT.007/RW.003, Cikokol, Kec. Tangerang, Kota Tangerang, Banten 15118

Warung Pojok, Jl. Ciwaru Raya No.73, Cipare, Kec. Serang, Kota Serang, Banten 42117

Correspondence Email: tsamanytrans@gmail.com

\begin{abstract}
The writing of this article starts from the problems that exist in the development situation in each region, especially in spatial planning, almost certainly has the same problem, such as the absence of consistent and strict licensing in development. Such as floods that occurred in urban areas of Jakarta, Bogor, Depok, Tangerang, Bekasi due to the development of the city. It is increasing the number of cpopulation, activities, and land requirements both for settlements and economic activities so that there is a change of function that should be used as a conservation area and green open space has turned into a residential area. This research uses the normative legal research method or discusses this problem more to the study of literature or secondary data. The normative legal analysis includes research on constitutional principles, research on legal systematics, research on the degree of vertical and horizontal synchronization, comparison of law, and history of law. Law enforcement on sustainable spatial planning is a very complex phenomenon with various approaches, both legal, social, political, economic and cultural issues so that for the benefit of the community, the interests of the government as well as the harmony of spatial planning, environmental sustainability needs supporting capacity of the environment and resources nature is included in the case of sustainable development.
\end{abstract}

KEYWORDS: Problems, Spatial Planning, Law Enforcement

\section{INTRODUCTION}

In an integrated manner in the development of an area and the development of ideology, politics, economy, social, culture, defense, and security of a nation and the State, which is the objective of opening the 1945 Constitution must be done transparently. (Ambarita, 2015; Koeswahyono, 2012; Rani, 2012) In line with the 
change in the political system and state administration of this nation, it has also changed the policy regarding spatial planning in an order that has changed both at the level of regulatory networks, decision-making policies and related institutions. (Astriani, 2014; Aziz, 2016; Mawardi, 2008; Setyati \& Utomo, 2015)

One of the problems of urban development today is one of them is spatial planning, and city development is increasingly dense with increasing population growth so that each region must have rules about spatial planning in the implementation of development. (Deviana et al., 2011; Junef, 2017; Kodoatie \& Sjarief, 2010) Every human being who lives life in this world certainly needs a specific space in carrying out every activity. In this case, an area that can be interpreted as a container or a place for a person or a large audience to carry out activities. In order to anticipate regional spatial planning problems in terms of realizing and maintaining sustainable development, through State policy, a regulation was formed with the enactment of Law No. 26 of 2007 concerning Spatial Planning. (Fitriana, 2014; Imran, 2013; Jazuli, 2017; Suharyo, 2017)

The chaotic public spatial planning in various regions in the country ultimately impacts the environment, which eventually results in floods, landslides, and others. Jakarta, Bekasi, Tangerang often experience flood disasters due to spatial violations. (Aminah, 2015; Gunarti, 2015; Koeswahyono, 2012; Windari, 2013)

Flooding problems that occur in urban areas of Jakarta, Bogor, Depok, Tangerang, Bekasi due to the development of the city and an increase in population, activities, and land needs both for settlements and also economic activity so that there is a change of function that should be used as a conservation area and green open space has been turned into a residential area. (Amaniyah et al., 2015; Silfiana, 2018) As a result of that, all the water catchment becomes narrower so that there is an increase in surface runoff and cause erosion and have an impact on silting rivers and lead to overflow of water and flooding. Besides, the riverbanks, on top of which there are buildings and culture of the community that positions the river as a place for waste and garbage disposal. (Hasibuan, 2016) Bopunjur area (Bogor-PuncakCianjur), which is geographically an upstream area, irregularities have occurred a lot like the number of villa buildings, hotels, and people's homes. The function of the Bopunjur area is to be a water and land conservation area, which protects the field below it to guarantee the availability of groundwater, settlement water and flood mitigation for the Bopunjur region and its downstream areas. The occurrence of deviations of land use both in the upstream and downstream areas of Jabodetabek Punjur is inseparable from the demands of economic sector interests that ignore environmental factors. (Parsa, 2014)

De facto development in Indonesia in its implementation does not rely on proper spatial planning. And sometimes abuse of power or abuse of power in the case of violations of the specified spatial layout. There are too many examples where spatial planning is developed for catchment areas, green areas, or residential 
areas, developed into commercial areas with high-rise buildings above. (Zuhri, 2012)

The problems that exist in the development situation in each region, especially in spatial planning, almost certainly have the same problems, such as the absence of consistent and strict licensing in development, other than that the development activities are not in line with the direction of infrastructure provision and the presence of residential environments with environmental quality that is below normal standards. On the other hand, development is also not based on a system of supervision of various forms of building permit violations effectively. Progress does not or does not pay attention to the harmony and integration between spatial licensing mechanisms and the implementation of an environmental impact analysis (EIA). (Aminah, 2015; Syahadat \& Subarudi, 2012; Windari, 2013)

All issues regarding development and the environment in each region basically rest on the fulfillment of the quality and existence of the existing urban spatial layout. Therefore, spatial planning can be said to be the basis and the main framework of overall city management. Therefore it is necessary to find a solution as a way out to overcome the problem, among others, by paying attention to essential elements in the management of urban spatial planning in Indonesia.

\section{METHODOLOGY}

Answering the problematic and legal dimensions in spatial planning according to law number 26 of 2007, this study uses normative legal research methods or discusses these issues more on literature review or secondary data. The normative legal research includes research on constitutional principles, research on legal systematics, research on the degree of vertical and horizontal synchronization, comparison of law, and history of law. (Soekanto \& Mamudji, 2010; Soekanto \& Mamuji, 2018)Also, data obtained from several literature such as journals relating to the title in writing this article as well as examining the laws and regulations regarding spatial planning.

\section{RESULTS AND DISCUSSION}

Before discussing further the spatial planning process implemented, first debating the meaning of spatial planning itself, article 1 number 5 of Law Number 26 the Year 2007 spatial planning is a system of spatial planning processes, spatial use, and spatial use control. Thus the essence of spatial planning is space planning, utilization, and power. (Koeswahyono, 2012) The regional spatial plan is a blueprint document that will be used as a guideline or policy direction for the province, district, and city in the utilization of spatial use control over a specified period. In this context, some principles must be followed, including the following:

1. The territory of the State of Indonesia as a place or place for humans and other living creatures to carry out their activities is a gift of God that is mighty to the Indonesian people.

2. The territory of the Republic of Indonesia is the entire territory of the State, including land, sea, and air-based on the applicable laws and regulations, including the sea and the continental shelf around it. 
3. Space includes land space, ocean space, and air space and natural resources contained therein for life and livelihood. Human activities and other living things require space as the location of various spatial uses or vice versa, and space can accommodate multiple events

Various kinds of problems that cover violations of spatial planning include the implementation of regional autonomy, as well as different other laws and regulations. The phenomenon of spatial use in Indonesia will always intersect and even contradict between aspects of spatial planning and spatial requirements in both industrial and tourism development, as has happened in some regions, which in addition to providing benefits in construction but also having adverse effects on society, This happens due to lack of careful planning, often even violating the spatial structure that has been determined by the local government. (Suharyo, 2017; Wirasaputri, 2006)

Obstacles that occur in the application of Law Number 26 of 2007 concerning Spatial Planning, there are many violations that vary, such as from the business community, and the ranks of self-government. (Douvere, 2008; Wirawan \& Tambunan, 2018) Regional Governments that enjoy the era of regional autonomy, in some ways through the products of Provincial Regulations and Governors 'Decrees, and also Regency / City Regulations and Regents / Mayors' Decrees may violate spatial planning, and do not pay attention to various legislations on it. Where does this matter even though it is explicitly stated that the regional government is obliged to obey and implement its regional spatial planning, in the aspect of national, national, and national interests, spatial planning is a national perspective for the welfare and peace of all Indonesian people. (Djakaria \& Husein, 2017; Samadikun, 2007)

The presence of a law that should justify the development process so that development products will have an impact on existing licensed products, even though until now law enforcement in violation of spatial planning still only prioritizes administrative sanctions which are based on local regulations as made by the provincial government, regency/city. Legal penalties given from the civil aspect are only in the form of compensation or recovery as in the original condition, while many that appear only in the form of statements have occurred environmental damage, spatial violations, and mutual disagreement between the parties. The presence of law in the spatial planning process is expected to work well because the law gives a sense of justice to the parties concerned. Regulatory institutions can make changes, improvements, or revocation of the regulations that have been set if it turns out that in its implementation, it does not show a sense of justice for the parties concerned, or there is a mistake in its determination. Legal issues become very important when conflicts occur, both conflicts of interest, conflicts between users, and others. Legal aspects clash with social, economic, and environmental elements. (Kodoatie \& Sjarief, 2010) 
Daoed Joesoef, in his book The Study of the Strategy of the Logic of National Resilience and Development, explained that the concept of development so far still has problems. First, it is partial and aloof. Each development project, which is handled separately, is indeed well calculated and efficient. However, once merged with other projects, everything becomes shaken up in the flow of life, which in reality integrates every effort into a network of relationships. It turns out that every development project is only reliable in its loneliness.(Joesoef, 2014) Second, it ignores the human aspects of the people (people) of Indonesia. The construction, he said, was aimed at meeting the people's needs for food, clothing, housing, health, and education. The development process often forgets that humans in their lives need not only "to have more," but also "to be more," especially for those who already feel educated.

Third, it is not at all associated with the concept of "Nation-State building," but with the increase in GNP, as if the rise in national income of the nation-state as an entity automatically becomes stronger. Fourth, ignoring the ethics of the future, the ethics that must be lived now for and for the future. The current generation always feels itself to be the heir of the country's natural wealth and therefore feels entitled to exploit the wealth arbitrarily. He must realize he is not an heir, but borrowers from future generations. Fifth, it does utilize the reasoning of various scientific disciplines, so development work is multidisciplinary. However, trusting a subject as a "leader" in thinking and acting interdisciplinary, namely economics. Of course, it could be in one project, in one place, for a certain period, the multidisciplinary tool becomes cross-disciplinary, where a discipline (economics) is considered "leading" because it has the most potential to be the initial mover of the mechanism of work. But in the next period, it may be replaced by other disciplines which are believed to be the determinants of final success, for example, anthropology, etc.

The implementation of spatial planning laws in the legal system in Indonesia, cannot be independent or independent, must also pay attention to the meaning and importance of other laws, including local government laws. Because after all spatial planning, it must harmonize the interests of the central government, provincial government, and district/city-regional government, by observing, understanding and harmonizing other legislation, through intensive and transparent coordination to equalize perception, for the welfare and peace of the Indonesian people especially in terms of spatial planning. As a State that uses governance in a unitary state, it can be distinguished in 2 (two) forms, namely: (1) a unitary state with a centralized system, and (2) a unitary state with a decentralized network. In a unitary republic with a centralized system, everything in the country is directly regulated and managed by the Central Government, and the regions only need to carry out immediately what has been instructed by the Central Government. Whereas in the Unitary State with a decentralized system, regions are given the 
opportunity and power to regulate and manage their households (regional autonomy), which is called the Autonomous Region.

Provincial, regency/city sustainable regional development must begin with sustainable urban spatial planning. Sustainable development will be formed if the use of space in it is managed appropriately and adhered together, to enable the implementation of economic, social, environmental, and institutional development optimally. These three aspects must be taken into account in urban planning and structuring because the choice of a particular plan and order will affect the growth and life that takes place in the area. (Zuhri, 2012)

Several things must be considered in development in each region so that spatial planning becomes the main issues that need attention, such as in managing and planning regional policymakers to pay more attention to the spatial document which contains the designation of future activities, program activities related to the efforts to realize the spatial plan and the parties (potentially) responsible for carrying out the programs/activities referred to above as well as the existence of a map of land use plans, as a basis for development permits. (Soerjodibroto, 2006)

\section{CONCLUSION}

Problems in spatial planning, as well as Implementation of Law Number 26 the Year 2007 regarding Spatial Planning, cannot be implemented in an ideal way, and this is possible for obstacles and a very rapid increase in population, which affects the supply of various needs in spatial planning. Besides, overlapping policies made by policymakers as well as the absence of proper planning in spatial planning that results in environmental damage and impact on natural disasters.

Law enforcement on sustainable spatial planning is a very complex phenomenon with various approaches, both legal, social, political, economic, and cultural issues so that for the benefit of the community, the interests of the government and harmony in spatial planning, environmental sustainability needs environmental support and resources nature is included in the case of sustainable development, so it cannot be denied, every region in Indonesia faces various problems in the field that must be addressed so that the development concepts and principles can be implemented in real life and by spatial law number 26 of 2007 concerning the spatial plan.

\section{Referencces}

Amaniyah, N., Agustino, L., \& Jumiati, I. E. (2015). Analisis Kebijakan Pengelolaan Terpadu Wilayah Jakarta, Bogor, Depok, Tangerang, Bekasi, Dan Cianjur (Jabodetabekjur) Sebagai Kawasan Megapolitan [PhD Thesis]. Universitas Sultan Ageng Tirtayasa.

Ambarita, B. (2015). Urgensi Undang-undang Keamanan Nasional Dalam Stabilitas dan Sinergitas Nasional. GENERASI KAMPUS, 8(1). 
Aminah, S. (2015). Konflik dan Kontestasi Penataan Ruang Kota Surabaya. Jurnal LabSosio, 20(1), 59-79.

Astriani, N. (2014). Implikasi kebijakan ruang terbuka hijau dalam penataan ruang di Jawa barat. Jurnal Ilmu Hukum, 8(2).

Aziz, M. (2016). Pengujian peraturan perundang-undangan dalam sistem peraturan perundang-undangan Indonesia. Jurnal Konstitusi, 7(5), 113-150.

Deviana, A., Kridasantausa, I., \& Suryadi, Y. (2011). Kajian Pemodelan Spasial Banjir Untuk Mendukung Kebijakan Sempadan Sungai dan Tata Ruang Wilayah (Studi Kasus Wilayah Pengembangan Baleendah) [PhD Thesis]. Tesis.

Djakaria, D. V. S., \& Husein, R. (2017). Efektivitas Kantor Pengendalian Pertanahan Daerah (KPPD) Dalam Pengendalian Pemanfaatan Ruang Melalui Izin Peruntukan Penggunaan Tanah (IPPT). Journal of Governance and Public Policy, 4(2), 253-293.

Douvere, F. (2008). The importance of marine spatial planning in advancing ecosystembased sea use management. Marine Policy, 32(5), 762-771.

Fitriana, E. D. (2014). Implementasi kebijakan tata ruang wilayah Dalam mewujudkan pembangunan kota berkelanjutan (Studi di Kabupaten Magetan). Jurnal Administrasi Publik, 2(2), 217-223.

Gunarti, W. (2015). Mendesain Ruang Publik Terbuka Di Bawah Jalan Layang: Sebuah Kajian Desain Dan Lingkungan. 4(01), 68-84.

Hasibuan, R. (2016). Analisis dampak limbah/sampah rumah tangga terhadap pencemaran lingkungan hidup. Jurnal Ilmiah Advokasi, 4(1), 42-52.

Imran, S. (2013). Fungsi tata ruang dalam menjaga kelestarian lingkungan hidup Kota Gorontalo. Jurnal Dinamika Hukum, 13(3), 457-467.

Jazuli, A. (2017). Penegakan Hukum Penataan Ruang dalam Rangka Mewujudkan Pembangunan Berkelanjutan. Jurnal Rechts Vinding: Media Pembinaan Hukum Nasional, 6(2), 263-282.

Joesoef, D. (2014). Studi Strategi: Logika Ketahanan dan Pembangunan Nasional. Penerbit Buku Kompas.

Junef, M. (2017). Penegakan Hukum dalam Rangka Penataan Ruang Guna Mewujudkan Pembangunan Berkelanjutan. Jurnal Rechts Vinding: Media Pembinaan Hukum Nasional, 6(2), 178-307.

Kodoatie, R. J., \& Sjarief, R. (2010). Tata ruang air. Penerbit Andi.

Koeswahyono, I. (2012). Hukum penatagunaan tanah dan penataan ruang di Indonesia: Problematika antara teks and konteks. Universitas Brawijaya Press.

Mawardi, M. A. (2008). Pengawasan dan keseimbangan antara DPR dan Presiden dalam sistem ketatanegaraan RI. Jurnal Hukum IUS QUIA IUSTUM, 15(1).

Parsa, I. W. (2014). BPHN: Laporan Akhir Tim Pengkajian Hukum tentang Penegakan Hukum Penataan Ruang dalam kerangka otonomi Daerah. Jakarta.

Rani, F. (2012). Strategi pemerintah Indonesia dalam meningkatkan keamanan wilayah perbatasan menurut perspektif sosial pembangunan. Jurnal Transnasional, 4(01).

Samadikun, B. P. (2007). Dampak pertimbangan ekonomis terhadap tata ruang kota jakarta dan bopunjur. Jurnal Presipitasi, 2(1), 34-38.

Setyati, R., \& Utomo, W. (2015). Implementasi kebijakan penataan ruang terbuka hijau kawasan perumahan Kota Banjarbaru. JKAP Uurnal Kebijakan Dan Administrasi Publik), 19(1), 59-70. 
Silfiana, S. (2018). OPTIMALISASI FUNGSI BADAN KERJASAMA PEMBANGUNAN (BKSP) DALAM RANGKA PEMBANGUNAN DAERAH KAWASAN JABODETABEKJUR. Jurnal Ekonomi-Qu, 8(2).

Soekanto, S., \& Mamudji, S. (2010). Penelitian Hukum Normatif. PT Raja Grafindo Persada.

Soekanto, S., \& Mamuji, S. (2018). Metodologi Penelitian Hukum (Filsafat, Teori dan Praktik). Rajawali Pers.

Soerjodibroto, G. (2006). Tata ruang dalam pembangunan kota yang berkelanjutan. KonradAdenauer-Stiftung.

Suharyo, S. (2017). Problematika Penegakan Hukum Penataan Ruang Dalam Pelaksanaan Otonomi Daerah. Jurnal Rechts Vinding: Media Pembinaan Hukum Nasional, 6(2), 171182.

Syahadat, E., \& Subarudi, S. (2012). Permasalahan penataan ruang kawasan hutan dalam rangka revisi rencana tata ruang wilayah provinsi. Jurnal Analisis Kebijakan Kehutanan, 9(2), 131-143.

Windari, R. A. (2013). Korelasi Yuridis Rencana Tata Ruang Wilayah Propinsi (RTRWP) Terhadap Keajegan Alam Bali. Media Komunikasi FPIPS, 11(1).

Wirasaputri, N. (2006). Proses Penyusunan Rencana Tata Ruang Untuk Menjaga Kelestarian Fungsi Lingkungan Hidup di Wilayah Propinsi Jawa Tengah [PhD Thesis]. Program Pasca Sarjana Universitas Diponegoro.

Wirawan, B., \& Tambunan, J. R. (2018). Challenges on Java's small city spatial planning. E\&ES, 158(1), 012054.

Zuhri, M. (2012). Aspek Hukum Perencanaan Tata Ruang Kawasan Perkotaan di Indonesia. Kanun Jurnal Ilmu Hukum, 14(3), 485-495. 